Article

\title{
Predicting Future European Breeding Distributions of British Seabird Species under Climate Change and Unlimited/No Dispersal Scenarios
}

\author{
Deborah J.F. Russell ${ }^{1,2, *}$, Sarah Wanless ${ }^{3}$, Yvonne C. Collingham ${ }^{4}$, Brian Huntley ${ }^{4}$ and \\ Keith C. Hamer ${ }^{1}$
}

1 School of Biology, University of Leeds, Leeds LS2 9JT, UK. E-Mail: K.C.Hamer@leeds.ac.uk

2 Sea Mammal Research Unit, University of St Andrews, St Andrews KY16 8LB, UK

3 Centre for Ecology \& Hydrology, Edinburgh EH26 0QB, UK; E-Mail: swanl@ceh.ac.uk

4 School of Biological and Biomedical Sciences, Durham University, Durham DH1 3LE, UK; E-Mails: y.c.collingham@durham.ac.uk (Y.C.C.); brian.huntley@durham.ac.uk (B.H.)

* Author to whom correspondence should be addressed; E-Mail: dr60@st-andrews.ac.uk; Tel.: +44-133-446-7281; Fax: +44-133-446-3443.

Academic Editor: Tom Oliver

Received: 13 August 2015 / Accepted: 20 October 2015 / Published: 2 November 2015

\begin{abstract}
Understanding which traits make species vulnerable to climatic change and predicting future distributions permits conservation efforts to be focused on the most vulnerable species and the most appropriate sites. Here, we combine climate envelope models with predicted bioclimatic data from two emission scenarios leading up to 2100, to predict European breeding distributions of 23 seabird species that currently breed in the British Isles. Assuming unlimited dispersal, some species would be "winners" (increase the size of their range), but over $65 \%$ would lose range, some by up to $80 \%$. These "losers" have a high vulnerability to low prey availability, and a northerly distribution meaning they would lack space to move into. Under the worst-case scenario of no dispersal, species are predicted to lose between $25 \%$ and $100 \%$ of their range, so dispersal ability is a key constraint on future range sizes. More globally, the results indicate, based on foraging ecology, which seabird species are likely to be most affected by climatic change. Neither of the emissions scenarios used in this study is extreme, yet they generate very different predictions for some species, illustrating that even small decreases in emissions could yield large benefits for conservation.
\end{abstract}


Keywords: climate envelope modelling; climate response surface; conservation; ecological niche modelling; extinction risk; foraging ecology; global warming; marine spatial planning; sea surface temperature; species distribution models

\section{Introduction}

A key impact of climatic change is on species' distributions [1-5]. It is imperative that changes in distribution can be predicted to ensure that expensive conservation efforts are concentrated in appropriate areas [6-11]. Climate envelope models (CEMs) have been used to predict future European distributions, and in some cases extinction probabilities, of a variety of taxa [12-14]. Using this technique, Thomas et al. [15] predicted that 15\%-37\% of $>1000$ plant and animal species would be "committed to extinction" by 2050 due to climatic change. However, impacts are likely to differ between species; Hill et al. [16] predicted a mean range size decline of $65 \%$ for northern British butterfly species by 2100 , but only a decline of $24 \%$ for southern species, presumably due to a lack of space available for northern species to move into. The validity of predictions based on CEMs is subject to a number of caveats and uncertainties [17-22]. These include the assumption of a species distribution being at equilibrium with its environment, extrapolation to non-analog climates (novel combinations of climatic conditions) and the failure of most CEM forecasts to take account of dispersal ability, adaptation capacity, potential novel biotic interactions, or population dynamics. As CEMs also do not account for impacts of climatic change on habitat availability, predictions concern potential broad-scale geographical ranges rather than fine-scale distributions. Even such broad-scale distributions may be impacted by biotic interactions [23,24], particularly food availability [25]; thus any climatic variables which are a proxy for resources should be incorporated. Araújo et al. [13] illustrated the importance of dispersal ability, predicting that by 2050 climatic change will result in a large proportion of amphibian and reptile species increasing their range size in Europe if dispersal is unlimited, but if dispersal is not possible the range size of most species would be reduced. The distributions of mobile species such as birds are expected to be able to track climatic change [26,27]. However, this may not be the case for species which are site faithful. For example, many seabird species are faithful to breeding colonies and even individual ledges, once they have recruited into the breeding population [28,29], although relatively poor local breeding success can result in emigration [30]. For many species, rapid changes in distribution will depend on recruitment of new breeders into non-natal colonies. Seabirds have delayed recruitment and some species spend the first few years of their life at sea, visiting various colonies before recruiting into the breeding population. Although recruitment can be related to the breeding success in prospective colonies [30,31], the formation of new colonies is often a protracted process [32], which may slow changes in distribution and affect the ability of some species to keep pace with climatic change. Hence it is important to examine predicted changes in species' distributions under conditions of both no and unlimited dispersal, thus providing worst- and best-case scenarios of future distributions $[7,15]$. This allows conservation efforts, including protection and even habitat creation, to be focused at key current and potential future sites.

The British Isles are of international importance for seabirds, supporting $>50 \%$ of the world population of several species $[33,34]$. Climatic variation has been shown to have a discernable effect on 
various aspects of seabird populations including breeding and migration phenology [35,36], breeding success [37] and population size. A recent study, using CEMs which incorporated bioclimatic variables such as winter/spring sea surface temperature (SST), demonstrated that seabird population sizes (18 species) in the British Isles are affected by climatic variation [38], particularly populations of species which are vulnerable to low marine prey availability [39]. Winter/spring SST is negatively associated with prey availability [40], and small seabird species with a narrow diet, short foraging range, restricted diving ability, high cost of foraging and little "spare time" in their energy budget are likely to be particularly vulnerable to low marine prey availability [39] and thus to changes in SST. In addition, Russell et al. [38] showed that the species whose distributions and population sizes were most sensitive to climatic variation had shown the least favourable population change between 1985 and 2010, a period when overall climatic suitability declined for all species considered. The results of that study provide support for the use of CEMs to examine the effects of climatic change on seabirds. Here we extend the CEMs generated in Russell et al. [38] to a further five species (because we are not constrained by the availability of population data) to investigate how European distributions of seabird species which breed in the British Isles (23 species) are predicted to change by 2100 . We do this by considering multiple scenarios: no and unlimited dispersal, and two different climate change scenarios. We also consider three General Circulation Models (GCMs) for both climatic scenarios to incorporate inter-model variability in predictions. In light of the relationships found in Russell et al. [38], we test the hypotheses that species which are predicted to have smaller range sizes (number of occupied grid cells) relative to their simulated ranges in 1985, i.e., "losers", will be those whose foraging ecology makes them vulnerable to reduced marine prey availability (Hypothesis i) and those with more northerly distributions as they may lack space to move into (Hypothesis ii).

\section{Experimental Section}

The bioclimatic variables used to fit the CEMs and to predict future distributions were mean temperature of the warmest month (MTWM), winter/spring sea surface temperature (SST) and rainfall during the breeding season (RAIN) which, separately, have been shown to affect seabird breeding success at individual colonies [37,41-43] and in combination have been shown to be related to seabird population sizes and distribution in the British Isles and Europe, respectively [38]. Climatic data from the period 1976 to 1985 (inclusive) were used to fit climate response surface models [12], a type of CEM, to European seabird breeding distribution (presence/absence) data. These distribution data were collected mainly between 1985 and 1988 and provided by the European Bird Census Council on a $\sim 50 \mathrm{~km}$ resolution [44]. Because seabirds are long lived, generally site-faithful species with delayed recruitment, their distributions are likely driven by the climate over multiple preceding years. We only considered climatic data up to 1985 on the basis that anomalous climate between 1986 and 1988 could have had a considerable influence on the mean climate even though it could not have affected the observed distribution in 1985, and likely had little effect on distributions between 1986-1988. We restricted the seabird distribution to coastal cells resulting in a maximum prevalence (number of occupied cells) of 1073. Area under the curve (AUC) of ROC plots (model goodness-of-fit) was calculated for each species by separating the dataset into a training and test datasets comprising $70 \%$ and $30 \%$ of the grid cells, respectively. The grid cells in the training and test datasets were chosen at random except that the 
same proportions of presences, absences and missing records in the original data were maintained. Models were generated using $70 \%$ of the data (training cells) and used to predict probability of occurrence for test cells (30\% of grid squares). See Russell et al. [38] for more details on model fitting.

The fitted CEMs were used to predict future seabird distributions in 2100 under different greenhouse gas emissions scenarios, which we retained in preference to the more-recently developed representative concentration pathways, which are consistent with a wide range of possible changes in future anthropogenic emissions but do not explicitly consider different socio-economic drivers [45]. For each GCM, we chose emission scenarios (A1b and A2) from the two emission families which assume the future focus will be on economic growth rather than on environmental protection. A1 assumes rapid economic growth with scenario A1b assuming a reliance on multiple energy sources, whereas A2 assumes slower and more fragmented economic growth and technological development than under the A1 scenarios, resulting in higher greenhouse gas emissions [46]. To increase the robustness of our results [47], we used predicted values of the bioclimatic variables from three of the nine leading general circulation models (GCMs). The three GCMs chosen represent the three potential levels of increase in global precipitation predicted by GCMs: low, mean and high, and thus span the uncertainty associated with this variable. Data from the three GCMs were downloaded from the Climate and Environmental Retrieving and Archiving (CERA) website: Global Environmental Model (mean precipitation increase), version 1 (HadGEM1) developed by the Hadley Centre for Climate Prediction and Research [48,49]; ECHAM5/MPI-OM (low precipitation increase; hereafter ECHAM) developed at the Max Planck Institute for Meteorology [50,51]; and GFDL GM 2.1 (high precipitation increase; hereafter GFDL) developed by the National Oceanic and Atmospheric Administration (NOAA), USA [52,53]. To predict distributions of seabirds in 2100, we used 30-year means of predicted climatic variables for the period 2071 to 2100 . To preserve observed spatial patterns in climatic variation whilst minimizing bias in the models, model anomalies were generated and added to observed climatic data (1961-1990) to produce future climatic data. Model anomalies were the differences between the predicted climates of 1971 to 1990 and of the 30 years leading up to 2100. A spline surface was fitted for each model to describe the spatial variation in these anomalies and to permit interpolation of anomalies to the centre point of each of the $833 \sim 50 \mathrm{~km} \times 50 \mathrm{~km}$ coastal grid cells included in the analysis (see following paragraph). The original resolutions for HadGEM1, GFDL and ECHAM climatic data were $1.875^{\circ} \times 1.25^{\circ}, 2.5^{\circ} \times 2.0^{\circ}$ and $1.5^{\circ} \times 1.5^{\circ}$, respectively.

A total of $1073 \sim 50 \mathrm{~km} \times 50 \mathrm{~km}$ grid cells was used in the CEMs which were calibrated using climatic data from 1976 to 1985 inclusive [38]. For this study 240 of these cells were excluded because sea ice was recorded in these cells in winter/spring during 1971 to 1990. To fit the CEMs, sea ice was converted to $-2{ }^{\circ} \mathrm{C}$, which is the approximate freezing temperature of sea water in the North Atlantic. However, the actual temperature of sea ice can be much lower than $-2{ }^{\circ} \mathrm{C}$ and thus in generating climatic data by combining climatic anomalies and observed data, future sea surface temperatures could not be predicted for these grid cells. This resulted in a coastal grid of $833 \sim 50 \mathrm{~km} \times 50 \mathrm{~km}$ cells with a maximum latitude of $74.4^{\circ}$. This means that Svalbard and Franz Josef Land were excluded from the future predictions (Figure 1a,b) although they were included when fitting the climate envelope models (Figure 1c). Running future bioclimatic data within the climate envelope models, a climatic suitability value was produced in each grid cell for each species, emissions scenario and GCM. Following Huntley et al. [12], the kappa threshold values, chosen to maximise the agreement between observed and simulated distribution in 1985, were used to categorise predicted climatic suitability values of grid cells into "climatically 
suitable" or "unsuitable", for each species. Predicted distributions in 2100 were then compared with the simulated distributions in 1985 rather than the observed distributions in 1985 [54] to allow more meaningful comparisons to be made, recognizing that species' distributions may be constrained by factors other than climate. To allow quantitative comparison between recent distributions and predicted future distributions, only the 833 grid cells available for the future predictions were considered in the simulated distributions in 1985.

We considered two separate indicators of changes in species' range sizes between the modelled distributions in 1985 and 2100 [54]: (i) the size of the predicted range in 2100 as a proportion of the simulated range size in 1985 (termed R); and; (ii) the overlap between the simulated distribution in 1985 and the predicted distribution in 2100 as a proportion of the simulated range size in 1985 (termed O). $\mathrm{R}$ assumes unlimited dispersal whereas $\mathrm{O}$ assumes no dispersal. The centre of the simulated breeding range in 1985 was calculated for each species as was the centre of the predicted future range. The centre of a range was defined as the mean latitude and longitude of a species' modelled European distribution (833 cells). The geodesic distances and bearings between the centres of the modelled distributions in 1985 and 2100 were also calculated.

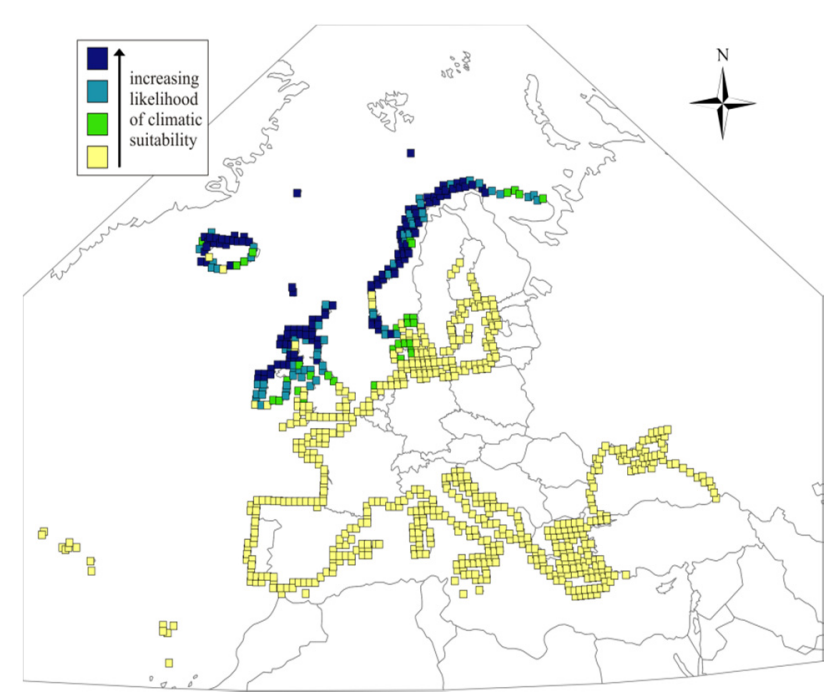

(a)

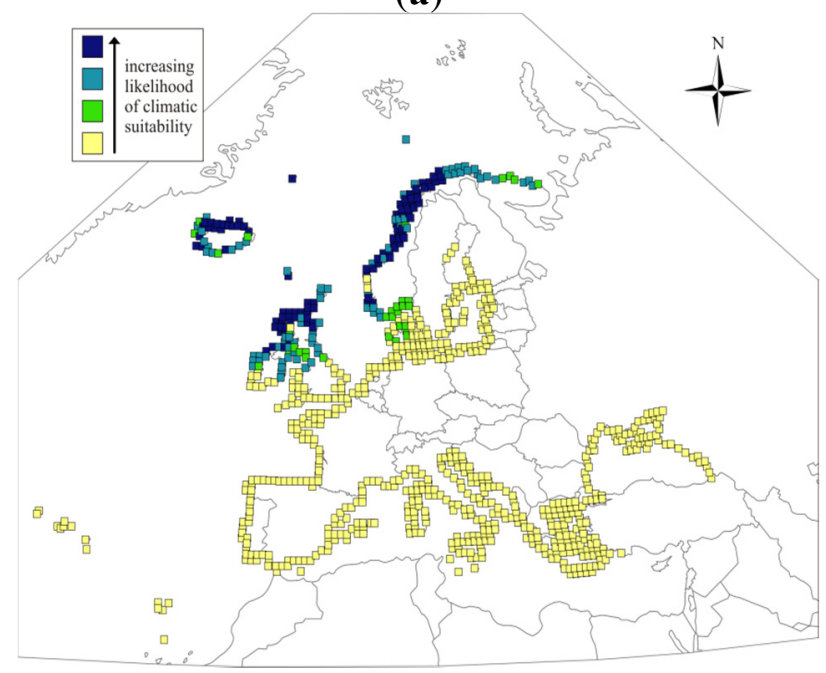

(b)

Figure 1. Cont. 


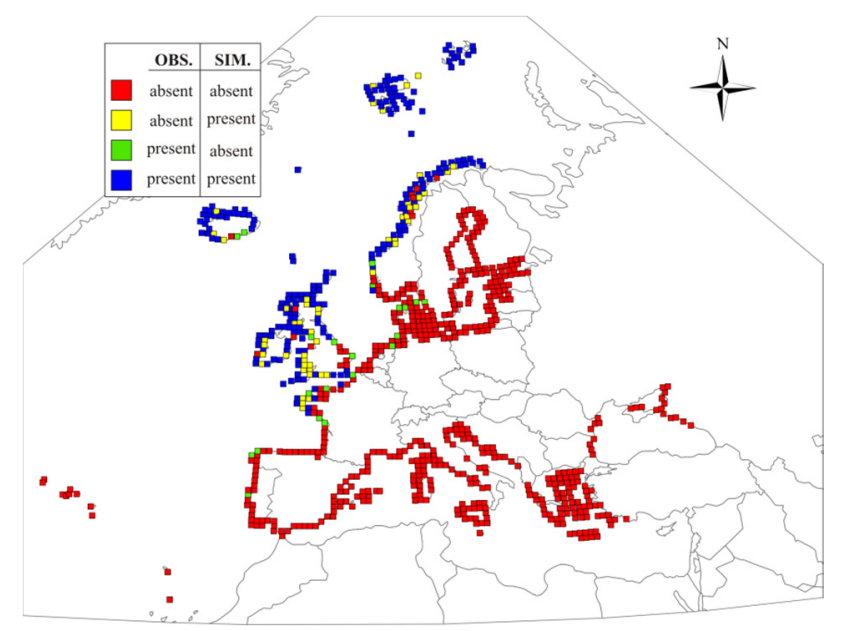

(c)

Figure 1. The potential European breeding distribution of the Black-legged Kittiwake in 2100 under emissions scenarios A1b (a) and A2 (b) based on climatic suitability predicted for the climatic scenarios derived from three General Circulation Models (GCMs) (yellow - unsuitable under all three GCMs; light green - suitable under one GCM; dark green — suitable under two GCMs; dark blue — suitable under all three GCMs); The observed (OBS) and simulated (SIM) distributions in 1985 are also shown for comparison (c).

We investigated, under both emissions scenarios, whether being a "winner" or "loser" (i.e., having a larger or smaller predicted range in 2100 than the simulated range in 1985 assuming unlimited dispersal) was influenced by a species' foraging ecology or latitudinal distribution in 1985 (median latitude of the 833 cells examined). Species' foraging ecology was represented as an independent index of the vulnerability of breeding success to reduced marine prey availability in the vicinity of colonies, derived from a combination of body size, energetic cost of foraging, potential foraging range, ability to dive, amount of "spare" time in the daily budget and ability to switch diet [39]. These traits were ranked 0 to 4 with 0 being least vulnerable to low marine prey availability (e.g., long foraging range) and then summed to produce an overall vulnerability score (maximum potential range 0 to 24). We also controlled for whether the species had low or high prevalence in Europe in 1985 (number of occupied cells; Table 1). The analysis was conducted using the mean R from the three GCMs within a generalised linear model (GLM) framework using a binomial error distribution. Backwards model selection was conducted using Akaike's information criterion, adjusted for small sample sizes (AICC) [55]. The analysis was carried out using the R language [56]. 
Table 1. The R (range) and O (overlap) values as a percentage of the 1985 simulated distribution, and the direction and geodesic distance that the range centre was predicted to move by 2100 under scenarios A1b and A2. Mean values from the three GCMs are shown. The vulnerability score [39] to low marine prey availability, prevalence, whether species have a southern range boundary in Europe and the goodness-of-fit value for the CEM models are shown (AUC). Vernacular names of species follow the International Ornithological Congress [57].

\begin{tabular}{|c|c|c|c|c|c|c|c|c|c|c|c|c|c|c|}
\hline \multirow[b]{2}{*}{ Species } & \multirow[b]{2}{*}{ Score } & \multirow[b]{2}{*}{ Prevalence * } & \multirow[b]{2}{*}{ AUC } & \multirow{2}{*}{$\begin{array}{c}\text { European } \\
\text { Southern Range } \\
\text { Boundary }\end{array}$} & \multicolumn{5}{|c|}{ A1b } & \multicolumn{5}{|c|}{ A2 } \\
\hline & & & & & $\mathbf{R}(\%)$ & O (\%) & $\begin{array}{c}\text { Distance } \\
\text { (km) }\end{array}$ & Direction & Forecast & $\mathbf{R}(\%)$ & $\mathbf{O}(\%)$ & $\begin{array}{c}\text { Distance } \\
\text { (km) }\end{array}$ & Direction & Forecast \\
\hline $\begin{array}{l}\text { European Storm Petrel } \\
\text { Hydrobates pelagicus }\end{array}$ & 10 & 84 & 0.82 & no & 101 & 15 & 1056 & $\mathrm{NE}$ & winner & 124 & 17 & 1200 & $\mathrm{NE}$ & winner \\
\hline $\begin{array}{l}\text { Leach's Storm Petrel } \\
\text { Oceanodroma leucorhoa }\end{array}$ & 10 & 12 & 0.83 & yes & 84 & 4 & 833 & $\mathrm{~N}$ & loser & 96 & 0 & 1238 & $\mathrm{~N}$ & loser \\
\hline $\begin{array}{l}\text { Northern Fulmar } \\
\text { Fulmarus glacialis }\end{array}$ & 7 & 198 & 0.97 & yes & 141 & 69 & 826 & $\mathrm{NE}$ & winner & 107 & 56 & 826 & $\mathrm{NE}$ & winner \\
\hline $\begin{array}{l}\text { Manx shearwater } \\
\text { Puffinus puffinus }\end{array}$ & 7 & 38 & 0.90 & no & 168 & 29 & 1055 & $\mathrm{NE}$ & winner & 169 & 28 & 1060 & $\mathrm{NE}$ & winner \\
\hline $\begin{array}{l}\text { Northern Gannet } \\
\text { Morus bassanus }\end{array}$ & 5 & 33 & 0.82 & yes & 94 & 41 & 341 & $\mathrm{~N}$ & loser & 84 & 29 & 331 & NW & loser \\
\hline $\begin{array}{c}\text { European Shag } \\
\text { Phalacrocorax aristotelis }\end{array}$ & 8 & 280 & 0.88 & no & 134 & 75 & 312 & SE & winner & 136 & 75 & 321 & SE & winner \\
\hline $\begin{array}{c}\text { Great Cormorant } \\
\text { Phalacrocorax carbo }\end{array}$ & 7 & 196 & 0.88 & no & 128 & 47 & 579 & NNW & winner & 128 & 43 & 578 & NNW & winner \\
\hline $\begin{array}{c}\text { Black-legged Kittiwake } \\
\text { Rissa tridactyla }\end{array}$ & 16 & 225 & 0.94 & yes & 80 & 70 & 244 & $\mathrm{NE}$ & loser & 75 & 65 & 303 & $\mathrm{~N}$ & loser \\
\hline $\begin{array}{c}\text { Mediterranean gull } \\
\text { Ichthyaetus melanocephalus }\end{array}$ & 11 & 42 & 0.88 & yes & 195 & 18 & 1335 & NW & winner & 200 & 16 & 1366 & NW & winner \\
\hline $\begin{array}{c}\text { Great Black-backed Gul } \\
\text { Larus marinus }\end{array}$ & 10 & 354 & 0.98 & yes & 67 & 60 & 294 & NW & loser & 63 & 58 & 330 & NW & loser \\
\hline $\begin{array}{c}\text { European Herring Gull } \\
\text { Larus argentatus }\end{array}$ & 11 & 419 & 0.97 & yes & 72 & 69 & 304 & $\mathrm{~N}$ & loser & 70 & 66 & 345 & $\mathrm{~N}$ & loser \\
\hline
\end{tabular}


Table 1. Cont.

\begin{tabular}{|c|c|c|c|c|c|c|c|c|c|c|c|c|c|c|}
\hline \multirow[b]{2}{*}{ Species } & \multirow[b]{2}{*}{ Score } & \multirow[b]{2}{*}{ Prevalence * } & \multirow[b]{2}{*}{ AUC } & \multirow{2}{*}{$\begin{array}{c}\text { European } \\
\text { Southern Range } \\
\text { Boundary } \\
\end{array}$} & \multicolumn{5}{|c|}{ A1b } & \multicolumn{5}{|c|}{ A2 } \\
\hline & & & & & R (\%) & $\mathbf{O}(\%)$ & $\begin{array}{c}\text { Distance } \\
(\mathbf{k m})\end{array}$ & Direction & Forecast & $\mathrm{R}(\%)$ & $\mathrm{O}(\%)$ & $\begin{array}{c}\text { Distance } \\
(\mathbf{k m})\end{array}$ & Direction & Forecast \\
\hline $\begin{array}{c}\text { Lesser Black-backed Gull } \\
\text { Larus fuscus }\end{array}$ & 11 & 350 & 0.93 & yes & 78 & 71 & 327 & $\mathrm{~N}$ & loser & 77 & 70 & 345 & $\mathrm{~N}$ & loser \\
\hline $\begin{array}{c}\text { Sandwich Tern } \\
\text { Thalasseus sandvicensis }\end{array}$ & 19 & 124 & 0.83 & yes & 100 & 42 & 791 & $\mathrm{~N}$ & loser & 113 & 47 & 774 & $\mathrm{~N}$ & winner \\
\hline $\begin{array}{c}\text { Little Tern } \\
\text { Sternula albifrons }\end{array}$ & 21 & 245 & 0.81 & no & 100 & 61 & 508 & $\mathrm{~N}$ & loser & 97 & 57 & 554 & NNW & loser \\
\hline $\begin{array}{c}\text { Roseate Tern } \\
\text { Sterna dougallii }\end{array}$ & 22 & 36 & 0.90 & no & 66 & 11 & 965 & $\mathrm{NE}$ & loser & 66 & 10 & 1265 & $\mathrm{NE}$ & loser \\
\hline $\begin{array}{l}\text { Common Tern } \\
\text { Sterna hirundo }\end{array}$ & 20 & 455 & 0.89 & no & 79 & 71 & 391 & NNW & loser & 75 & 68 & 445 & NNW & loser \\
\hline $\begin{array}{c}\text { Arctic Tern } \\
\text { Sterna paradisaea }\end{array}$ & 22 & 380 & 0.96 & yes & 52 & 50 & 353 & $\mathrm{~N}$ & loser & 48 & 47 & 408 & $\mathrm{~N}$ & loser \\
\hline $\begin{array}{c}\text { Great Skua } \\
\text { Stercorarius skua }\end{array}$ & 13 & 65 & 0.95 & yes & 85 & 22 & 618 & $\mathrm{~N}$ & loser & 68 & 15 & 693 & $\mathrm{~N}$ & loser \\
\hline $\begin{array}{c}\text { Parasitic Jaeger } \\
\text { Stercorarius parasiticus }\end{array}$ & 15 & 230 & 0.97 & yes & 24 & 24 & 869 & WNW & loser & 20 & 19 & 914 & WNW & loser \\
\hline $\begin{array}{c}\text { Common Murre } \\
\text { Uria aalge }\end{array}$ & 9 & 145 & 0.87 & yes & 111 & 62 & 667 & $\mathrm{NE}$ & winner & 103 & 54 & 718 & $\mathrm{NE}$ & winner \\
\hline $\begin{array}{l}\text { Razorbill } \\
\text { Alca torda }\end{array}$ & 12 & 182 & 0.90 & yes & 88 & 48 & 485 & $\mathrm{~N}$ & loser & 83 & 44 & 516 & $\mathrm{~N}$ & loser \\
\hline $\begin{array}{c}\text { Black Guillemot } \\
\text { Cepphus grylle }\end{array}$ & 14 & 287 & 0.97 & yes & 64 & 62 & 251 & NW & loser & 59 & 57 & 294 & NW & loser \\
\hline $\begin{array}{c}\text { Atlantic Puffin } \\
\text { Fratercula arctica }\end{array}$ & 13 & 142 & 0.93 & yes & 72 & 43 & 365 & $\mathrm{NE}$ & loser & 61 & 35 & 435 & $\mathrm{~N}$ & loser \\
\hline mean & & & & & 95 & 46 & 599 & & & 92 & 42 & 663 & & \\
\hline
\end{tabular}

*: Prevalence refers to of grid-squares occupied by each species within Europe. 


\section{Results and Discussion}

Large changes in climate were predicted to occur between the period used to generate the climate envelope models (1976-1985) and the 30 years leading up to 2100 (Table S1). For all models and both emissions scenarios, on average MTWM and SST were predicted to increase between the two time periods, and RAIN to decrease. As expected, the predicted magnitude of these changes was greater under the A2 scenario than the A1b scenario. The observed and simulated distributions in 1985, as well as the predicted distributions under A1b and A2, are shown in Figure 1 for Black-legged Kittiwake (Rissa tridactyla, see Figures S1-S22 in Supplementary Material for all other species). The likelihood that a grid cell would be climatically suitable for a species was considered to increase with the number of GCMs predicting this to be the case (Figure 1; Figures S1-S22). The reliability of predictions of species distributions depends on the degree to which distributions in 1985 were determined by climatic variables, as indicated by the AUC values for the CEMs (goodness-of-fit; Table 1). The goodness-of-fit values for the species investigated here all indicated that predictions based on the models would be useful or highly useful [58]. For the majority of species (16/23) the southern boundary of their range is within Europe and thus their complete climate envelope was considered, meaning future predictions were more reliable (Table 1) than for those species for which the climate envelope was not completely defined [59]. Although the southern range boundary for Leach's Storm Petrel (Oceanodroma leucorhoa) was within Europe, the low prevalence of this species, may have affected the reliability of predictions [60]. The predicted species' range size (number of cells predicted to be suitable) differed markedly according to whether unlimited or no dispersal was assumed (Table 1). Under the assumption of unlimited dispersal, between $65 \%$ and $70 \%$ of the 23 species were expected to be "losers". The mean range size in 2100 was predicted to be $95 \%$ (range: $24 \%$ to $195 \%$ ) and $92 \%$ (range: $19 \%$ to $200 \%$ ) of the simulated range size in 1985 under the A1b and A2 scenarios, respectively. Under the alternative assumption of no dispersal, all species were expected to lose at least $25 \%$ of their range. The mean range size in 2100 was predicted to be reduced to $46 \%$ (range: $4 \%$ to $76 \%$ ) and $42 \%$ (range: $0 \%$ to $75 \%$ ) of the simulated range size in 1985, under scenario A1b and A2, respectively (Table 1). In this study, all species were predicted to shift their ranges northwards between 1985 and 2100 as a result of climatic change, with the exception of European Shag (Phalacrocorax aristotelis) whose distribution was predicted to move south east. This may be partly because Svalbard and Franz Josef Land, which may become climatically suitable for European Shag in 2100, were not included here. Furthermore, it was predicted that some areas in Western Europe (e.g., Spain) will no longer be suitable for European Shag whereas areas in south east Europe, specifically the coast of the Black Sea, will become suitable (Figure S6). Currently, the Black Sea has a lower winter/spring SST than the Mediterranean Sea and the warming of the Black Sea would make it more climatically suitable for the European Shag, which as a partial migrant, is particularly sensitive to the local environment [36]. The general northward trend in species' distribution is in agreement with observed changes in species' distributions across a range of taxa [61-63].

In support of hypothesis (i) we found that "losers" (under unlimited dispersal) were those species which had the highest vulnerability to low prey availability (Furness and Tasker; GLM: A1b; $\mathrm{X}^{2}{ }_{1,20}=17.3, p<0.0001, \mathrm{~A} 2 ; \mathrm{X}^{2}{ }_{1,20}=11.1, p<0.001$; Figure 2). In support of hypothesis (ii) these "losers" also had a more northern distribution (GLM: A1b; $\mathrm{X}^{2}{ }_{1,20}=11.4, p<0.001, \mathrm{~A} 2 ; \mathrm{X}^{2}{ }_{1,20}=12.5$, $p<0.001$; Figure 3). This is likely to be because northerly species will be more constrained in terms of 
available land to colonise, as suitable climate conditions become less available in the environment. For species such as European Herring Gull (Larus argentatus), Lesser Black-Backed Gull (Larus fuscus) and Common Tern (Sterna hirundo), their low R value may be partly because of the exclusion from the analyses of Svalbard and Franz Josef Land which they may, in reality, colonise. Whether a species was a "winner" or "loser" was not affected by its prevalence (number of occupied grid cells in 1985; Table 1), as this variable was not retained in the model.

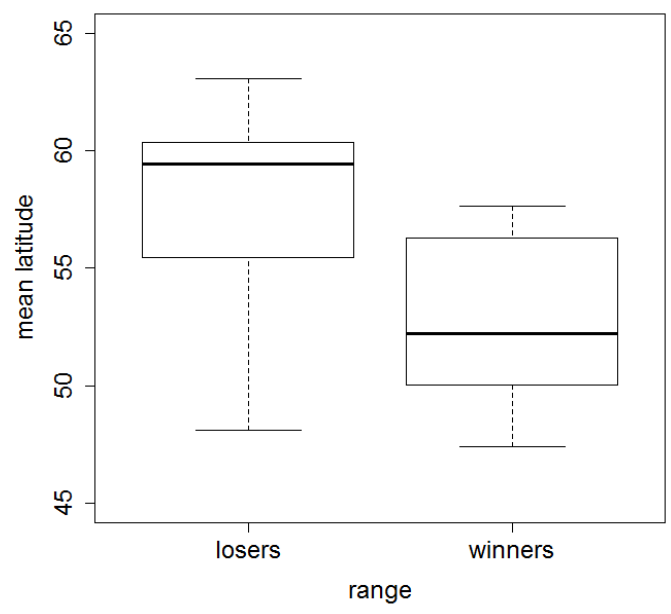

(a)

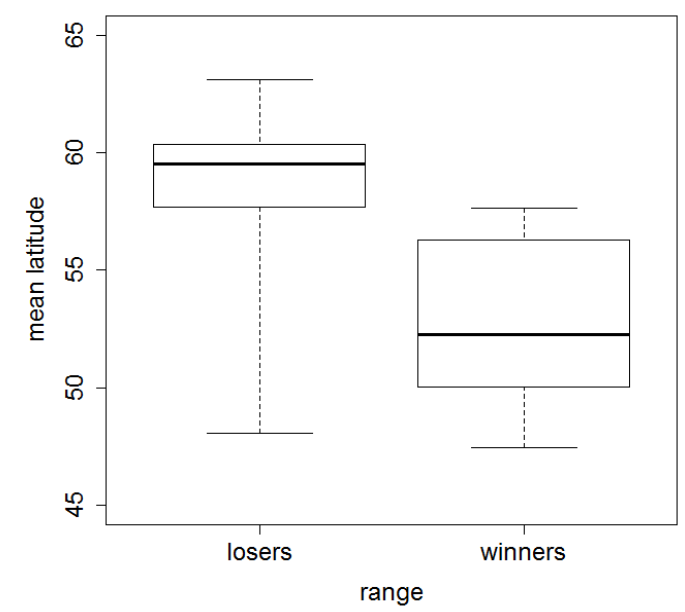

(b)

Figure 2. The relationship between mean latitude and whether a species was a "winner" or "loser", in terms of changes in range size (number of grid cells predicted as climatically suitable), under emissions scenarios A1b (a) and A2 (b). Horizontal lines indicate median values; bottom and top of the boxes indicate 25 th and 75 th percentiles, respectively; and the error bars show $95 \%$ confidence intervals.

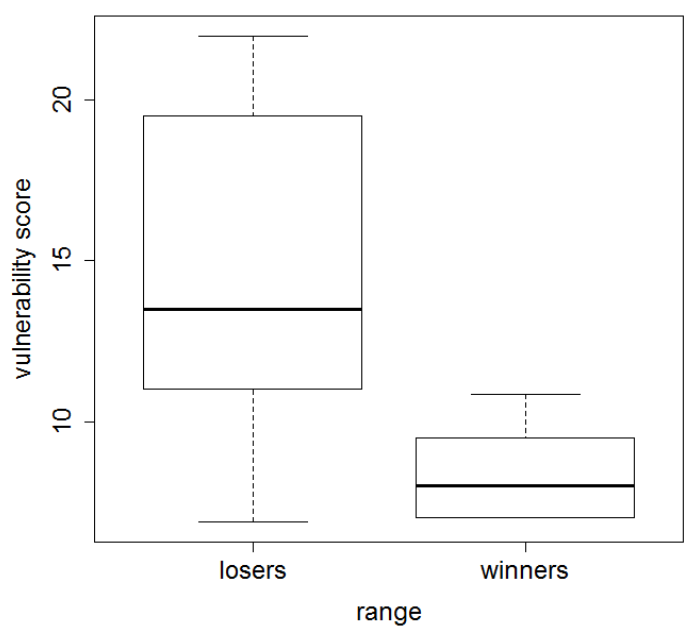

(a)

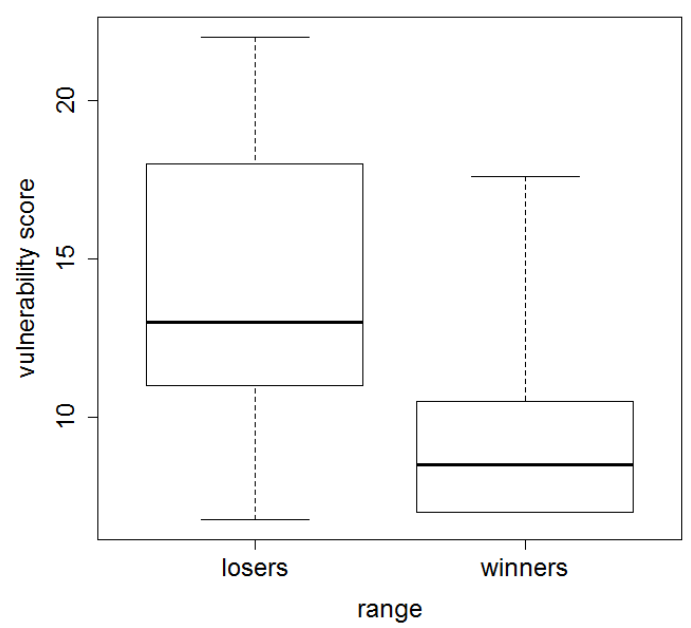

(b)

Figure 3. The relationship between vulnerability score to low prey availability [39] and whether a species was a "winner" or "loser", in terms of changes in range size (number of grid cells predicted as climatically suitable), under emissions scenarios A1b (a) and A2 (b). Horizontal lines indicate median values; the bottom and top of the boxes indicate 25 th and 75th percentiles, respectively; and the error bars show 95\% confidence intervals. 
Assuming the best case scenario of unlimited dispersal, three species (Leach's Storm Petrel; Great Skua, Stercorarius skua; and Parasitic Jaeger, Stercorarius parasiticus) were predicted to become close to or completely extinct in the British Isles, depending on the emissions scenario. Furthermore, the range sizes of other species in Britain such as Black-legged Kittiwake, Arctic Tern (Sterna paradisea) and the auks (Alcidae) were expected to decrease considerably. These findings are of concern for seabird conservation in the British Isles and in some cases of great concern for the European and global conservation of species; the British Isles holds approximately $60 \%$ of the global population of Great Skua (Mitchell et al., 2004). In Europe, there were predicted decreases in range size of least $25 \%$ for Great Black-backed Gull (Larus marinus), European Herring Gull, Roseate Tern (Sterna dougallii), Arctic Tern, Great Skua, Parasitic Jaeger, Black Guillemot (Cepphus grylle) and Atlantic Puffin (Fratercula arctica). Black-legged Kittiwake was also included in the above list under scenario A2. Of particular concern is Parasitic Jaeger whose range in 2100 was predicted to be only $24 \%$ of the size of its simulated range in 1985 under scenario A1b and only 20\% under scenario A2. Fortunately, with the exception of Great Skua, species which are endemic or near endemic to Europe (European Storm Petrel, Hydrobates pelagicus; European Shag; and Mediterranean Gull, Ichthyaetus melanocephalus) were predicted to increase their modelled range size between 1985 and 2100, providing they can successfully disperse, and suitable breeding and foraging habitat is available. However, this does not negate global conservation concern for non-endemic European species whose range sizes are predicted to decrease as the other main stronghold for these species is North America which will also be subject to climatic warming.

Some species predicted to become "winners" under unlimited dispersal were predicted to be the biggest "losers" if no dispersal was assumed. This is particularly worrying in the case of Manx Shearwater (Puffinus puffinus) and Northern Gannet (Morus bassanus), for which Europe holds a large proportion of the global population. The greatest "winner" assuming unlimited dispersal was Mediterranean Gull, whose range size in 2100 was predicted to be almost double the size in 1985, but under no dispersal this species was predicted to retain less than $20 \%$ of its range. Due to the high degree of colony fidelity once individuals recruit into a breeding colony, and the long life span of species studied here ( $>10$ years) [32], rapid range shifts will rely on recruitment of first time breeders into non-natal colonies. Recruitment levels into natal colonies vary between species, estimated at $90 \%$ for Northern Fulmar (Fulmarus glacialis) [64] and European Shag [28]; 70\% for European Herring Gull [65], 81\% for Common Murre (Uria aalge) [66], 83\% for Razorbill (Alca torda) [67], 50\% for Black Guillemot [68], and 38\% for Atlantic Puffin [29]. However, these are only estimates and levels of philopatry can vary between sexes [69], as well as between colonies [70], with colony-specific factors influencing dispersal differently in different species [71]. For example, although size of potential colonies does not affect the level of philopatry in Arctic Tern, philopatry is positively correlated with the distance to potential colonies [72], whereas in Black-legged Kittiwake the level of philopatry is associated with relative colony size and the age of potential colonies [70], but not with distance [73]. So not only may distance to potential sites restrict dispersal, but in some species individuals will also preferentially recruit into older populations of a larger size, reducing the likelihood of new colonies being founded. However, in Black-legged Kittiwake attendance of prospectors is dependent on local breeding success [31] which would be predicted to be higher in climatically suitable versus unsuitable areas [37], providing colony formation had occurred. Consequently, although seabirds are highly mobile the social constraints in forming colonies may slow range adjustments especially if local extinction 
means species have to disperse large distances. However, low levels of current dispersal do not preclude seabirds from high levels of dispersal in the future under increased dispersal pressure [74]. For example, Northern Fulmar expanded its breeding distribution greatly over the past 200 years [75]. Although there are three main hypotheses [76-78] as to the cause of the expansion, all implicate changes in food resources [75]. This suggests that at least some seabird species may be able to track changes in prey distribution induced by climatic change. The scenarios of no and unlimited dispersal are likely to be unrealistic [21] but provide lower and upper confidence intervals within which the true dispersal extent will lie. To obtain more precise predictions of species distributions under climatic change, future research needs to focus on how dispersal ability and colony formation are influenced by climatic change.

This study builds on a broader analysis by Huntley et al. [54] that used generic environmental covariates within CEMs to predict distributions of European breeding birds in 2100. Huntley et al. [54] produced predictions based on the A2 and B2 emissions scenarios, using the same three GCMs, but a generation prior to those used here. Assuming no dispersal, the results under scenario A2 were very similar between seabirds (this study) and European birds in general, with mean species overlap of $42 \%$ and $41 \%$, respectively. However, under unlimited dispersal, on average seabirds are expected to fare much better than European birds as a whole, with a mean predicted range size in 2100 of $92 \%$ of their simulated range size in 1985 for seabirds in comparison to $79 \%$ for the general study. This contrast suggests that, in general, the seabirds studied here have a similar sensitivity to climatic change as other European birds, but that there was predicted to be relatively more climatically suitable space available in the future for seabirds than for other birds.

\section{Conclusions}

This study provides minimum (no dispersal) and maximum (unlimited dispersal) predicted European breeding distributions in 2100 for those seabirds that currently breed in the British Isles. Due to constraints of habitat availability and biotic interactions, these models should be regarded as predicting potential broad-scale rather than fine-scale distributions. In reality species distributions are also likely to be impacted by novel biotic interactions between species $[79,80]$ and habitat change; such effects are difficult to predict as they can be additive, negative or positive. For example, although climatic change is likely to reduce the availability of some key prey species such as Lesser Sandeel (Ammodytes marinus) [40], it may result in increased abundance of others, such as the European Anchovy (Engraulis encrasicolus) [81,82]. Nonetheless, our results have implications for conservation and marine spatial planning. They indicate which currently occupied sites should be prioritized in terms of conservation of both breeding and foraging habitat to preserve populations within regions which will remain climatically suitable. We also identified currently unoccupied regions that are likely to become suitable in the future, allowing appropriate breeding habitat and adjacent foraging habitat to be identified and protected. In addition, our study demonstrates which species are likely to be of greatest conservation concern in both a UK and European context. More broadly, we highlight that the seabird species most likely to lose range as a result of climatic change are those that breed at higher latitudes and whose foraging ecology makes them vulnerable to low prey availability. However, even lower-latitude species that are not particularly vulnerable to low food availability are predicted to show decreases in breeding range if their scale and rate of natal dispersal does not allow them to keep pace with the changing climate. Finally, the emissions 
scenarios used in this study generate very different trajectories for some species, illustrating that even small decreases in greenhouse gas emissions can yield large benefits for conservation.

\section{Supplementary Materials}

Supplementary materials can be accessed at: http://www.mdpi.com/1424-2818/7/4/342/s1.

\section{Acknowledgments}

We thank the European Bird Census Council for their data on European seabird distributions. Deborah J.F. Russell was supported by NERC UKPopNet. We appreciate the comments from two referees which greatly improved the manuscript.

\section{Author Contributions}

Keith C. Hamer, Sarah Wanless, Brian Huntley and Deborah J.F. Russell conceived the study. Deborah J.F. Russell and Yvonne C. Collingham prepared the data and ran the climate envelope models. Deborah J.F. Russell conducted the analysis and wrote the paper. All authors commented on the paper.

\section{Conflicts of Interest}

The authors declare no conflict of interest.

\section{References}

1. Hughes, L. Biological consequences of global warming: Is the signal already. Trends Ecol. Evol. 2000, 15, 56-61.

2. McCarty, J.P. Ecological consequences of recent climate change. Conserv. Biol. 2001, 15, 320-331.

3. Walther, G.-R.; Post, E.; Convey, P.; Menzel, A.; Parmesan, C.; Beebee, T.J.C.; Fromentin, J.-M.; Hoegh-Guldberg, O.; Bairlein, F. Ecological responses to recent climate change. Nature 2002, 416, 389-395.

4. Chen, I.-C.; Shiu, H.-J.; Benedick, S.; Holloway, J.D.; Chey, V.K.; Barlow, H.S.; Hill, J.K.; Thomas, C.D. Elevation increases in moth assemblages over 42 years on a tropical mountain. Proc. Natl. Acad. Sci. USA 2009, 106, 1479-1483.

5. Lehikoinen, A.; Jaatinen, K.; Vähätalo, A.V.; Clausen, P.; Crowe, O.; Deceuninck, B.; Hearn, R.; Holt, C.A.; Hornman, M.; Keller, V.; et al. Rapid climate driven shifts in wintering distributions of three common waterbird species. Global Chang. Biol. 2013, 19, 2071-2081.

6. Berry, P.M.; Dawson, T.P.; Harrison, P.A.; Pearson, R.G. Modelling potential impacts of climate change on the bioclimatic envelope of species in Britain and Ireland. Global Ecol. Biogeogr. 2002, $11,453-462$.

7. Araújo, M.B.; Cabeza, M.; Thuiller, W.; Hannah, L.; Williams, P.H. Would climate change drive species out of reserves? An assessment of existing reserve-selection methods. Global Chang. Biol. 2004, 10, 1618-1626.

8. Barry, S.; Elith, J. Error and uncertainty in habitat models. J. Appl. Ecol. 2006, 43, 413-423. 
9. Hijmans, R.J.; Graham, C.H. The ability of climate envelope models to predict the effect of climate change on species distributions. Global Chang. Biol. 2006, 12, 2272-2281.

10. Brooker, R.W.; Travis, J.M.J.; Clark, E.J.; Dytham, C. Modelling species' range shifts in a changing climate: The impacts of biotic interactions, dispersal distance and the rate of climate change. J. Theor. Biol. 2007, 245, 59-65.

11. Willis, K.J.; Araújo, M.B.; Bennett, K.D.; Figueroa-Rangel, B.; Froyd, C.A.; Myers, N. How can a knowledge of the past help to conserve the future? Biodiversity conservation and the relevance of long-term ecological studies. Philos. Trans. R. Soc. Lond. B. Biol. Sci. 2007, 362, 175-186.

12. Huntley, B.; Berry, P.M.; Cramert, W.; Environmental, A.P.M. Modelling present and potential future ranges of some European higher plants using climate response surfaces. J. Biogeogr. 1995, 22, 967-1001.

13. Araújo, M.B.; Thuiller, W.; Pearson, R.G. Climate warming and the decline of amphibians and reptiles in Europe. J. Biogeogr. 2006, 33, 1712-1728.

14. Levinsky, I.; Skov, F.; Svenning, J.-C. Potential impact of climate change on the distribuions and civersity patterns of European mammals. Biodivers. Conserv. 2007, 16, 3803-3816.

15. Thomas, C.D.; Cameron, A.; Green, R.E.; Bakkenes, M.; Beaumont, L.J.; Collingham, Y.C.; Erasmus, B.F.N.; de Siqueira, M.F.; Grainger, A.; Hannah, L.; et al. Extinction risk from climate change. Nature 2004, 427, 145-148.

16. Hill, J.K.; Thomas, C.D.; Fox, R.; Telfer, M.G.; Willis, S.G.; Asher, J.; Huntley, B. Responses of butterflies to twentieth century climate warming: Implications for future ranges. Proc. Biol. Sci. 2002, 269, 2163-2171.

17. Pearson, R.G.; Dawson, T.P. Predicting the impacts of climate change on the distribution of speces: Are bioclimate envelope models useful? Global Ecol. Biogeogr. 2003, 12, 361-371.

18. Thuiller, W. Climate change and the ecologist. Nature 2007, 448, 550-552.

19. Fitzpatrick, M.C.; Weltzin, J.F.; Sanders, N.J.; Dunn, R.R. The biogeography of prediction error: Why does the introduced range of the fire ant over-predict its native range? Global Ecol. Biogeogr. 2007, 16, 24-33.

20. Beale, C.M.; Lennon, J.J.; Gimona, A. Opening the climate envelope reveals no macroscale associations with climate in European birds. Proc. Natl. Acad. Sci. USA 2008, 105, 14908-14912.

21. Guisan, A.; Thuiller, W. Predicting species distribution: Offering more than simple habitat models. Ecol. Lett. 2005, 8, 993-1009.

22. Fitzpatrick, M.C.; Hargrove, W.W. The projection of species distribution models and the problem of non-analog climate. Biodivers. Conserv. 2009, 18, 2255-2261.

23. Wisz, M.S.; Pottier, J.; Kissling, W.D.; Pellissier, L.; Lenoir, J.; Damgaard, C.F.; Dormann, C.F.; Forchhammer, M.C.; Grytnes, J.A.; Guisan, A.; et al. The role of biotic interactions in shaping distributions and realised assemblages of species: Implications for species distribution modelling. Biol. Rev. 2013, 88, 15-30.

24. De Araújo, C.B.; Marcondes-Machado, L.O.; Costa, G.C. The importance of biotic interactions in species distribution models: A test of the Eltonian noise hypothesis using parrots. J. Biogeogr. 2014, $41,513-523$. 
25. Cahill, A.E.; Aiello-Lammens, M.E.; Fisher-Reid, M.C.; Hua, X.; Karanewsky, C.J.; Yeong Ryu, H.; Sbeglia, G.C.; Spagnolo, F.; Waldron, J.B.; Warsi, O.; et al. How does climate change cause extinction? Proc. R. Soc. B Biol. Sci. 2013, 280, 1-9.

26. Graham, R.W.; Grimm, E.C. Effects of global climate change on the patterns of terrestrial biological communities. Trends Ecol. Evol. 1990, 5, 289-292.

27. Yvonne, C.; Mark, O.; Collingham, Y.C.; HIll, M.O.; Huntley, B. The migration of sessile organisms: A simulation model with measurable parameters. J. Veg. Sci. 1996, 7, 831-846.

28. Barlow, E.J.; Daunt, F.; Wanless, S.; Reid, J.M. Estimating dispersal distributions at multiple scales: Within-colony and among-colony dispersal rates, distances and directions in European Shags Phalacrocorax aristotelis. Ibis 2013, 155, 762-778.

29. Harris, M.P.; Wanless, S. The Puffin; T \& AD Poyser: London, UK, 2011.

30. Danchin, E.; Boulinier, T.; Massot, M. Conspecific reproductive success and breeding habitat selection: implications for the study of coloniality. Ecology 1998, 79, 2415-2428.

31. Boulinier, T.; McCoy, K.D.; Yoccoz, N.G.; Gasparini, J.; Tveraa, T. Public information affects breeding dispersal in a colonial bird: Kittiwakes cue on neighbours. Biol. Lett. 2008, 4, 538-540.

32. Schreiber, E.A.; Burger, J. Biology of Marine Birds; CRC Press: Boca Raton, FL, USA, 2002.

33. Mitchell, P.I.; Newton, S.F.; Ratcliffe, N.; Dunn, T.E. Seabird Populations of Britain and Ireland: Results of the Seabird 2000 Census; T. \& A.D. Poyser: London, UK, 2004.

34. Thaxter, C.B.; Lascelles, B.; Sugar, K.; Cook, A.S.C.P.; Roos, S.; Bolton, M.; Langston, R.H.W.; Burton, N.H.K. Seabird foraging ranges as a tool for identifying Marine Protected Areas. Biol. Conserv. 2012, 156, 53-61.

35. Barbraud, C.; Weimerskirch, H. Antarctic birds breed later in response to climate change. Proc. Natl. Acad. Sci. USA 2006, 103, 6248-6251.

36. Frederiksen, M.; Harris, M.P.; Daunt, F.; Rothery, P.; Wanless, S. Scale-dependent climate signals drive breeding phenology of three seabird species. Global Chang. Biol. 2004, 10, 1214-1221.

37. Frederiksen, M.; Wanless, S.; Harris, M.P.; Rothery, P.; Wilson, L.J. The role of industrial fisheries and oceanographic change in the decline of North Sea black-legged kittiwakes. J. Appl. Ecol. 2004, 41, 1129-1139.

38. Russell, D.J.F.; Wanless, S.; Collingham, Y.C.; Anderson, B.J.; Beale, C.; Reid, J.B.; Huntley, B.; Hamer, K.C. Beyond climate envelopes: Bio-climate modelling accords with observed 25-year changes in seabird populations of the British Isles. Divers. Distrib. 2015, 21, 211-222.

39. Furness, R.W.; Tasker, M. Seabird-fishery interactions: Quantifying the sensitivity of seabirds to reductions in sandeel abundance, and identification of key areas for sensitive seabirds in the North Sea. Mar. Ecol. Prog. Ser. 2000, 202, 253-264.

40. Arnott, S.; Ruxton, G. Sandeel recruitment in the North Sea: Demographic, climatic and trophic effects. Mar. Ecol. Prog. Ser. 2002, 238, 199-210.

41. Oswald, S.A.; Bearhop, S.; Furness, R.W.; Huntley, B.; Hamer, K.C. Heat stress in a high-latitude seabird: Effects of temperature and food supply on bathing and nest attendance of great skuas Catharacta skua. J. Avian Biol. 2008, 39, 163-169.

42. Thompson, K.R.; Furness, R.W. The influence of rainfall and nest-site quality on the population-dynamics of the Manx Shearwater Puffinus puffinus on Rhum. J. Zool. 1991, 225, 427-437. 
43. Gray, C.; Phillips, R.; Hamer, K. Non-random nestling mortality in northern fulmars: Implications for monitoring marine environments. J. Zool. 2003, 259, 109-113.

44. Hagemeijer, W.J.M.; Blair, M.J. The EBCC Atlas of European Breeding Birds. Their Distribution and Abundance; T. \& A.D. Poyser: London, UK, 1997.

45. Collins, M.; Knutti, R.; Arblaster, J.; Dufresne, J.-L.; Fichefet, T.; Friedlingstein, P.; Gao, X.; Gutowski, W.; Johns, T.; Krinner, G.; et al. Long-term Climate Change: Projections, Commitments and Irreversibility. In Climate Change 2013: The Physical Science Basis. Contribution of Working Group I to the Fifth Assessment Report of the Intergovernmental Panel on Climate Change; Stocke, T., Qin, D., Plattner, G., Tignor, M., Allen, S., Boschung, J., Nauels, A., Xia, Y., Bex, V., Midgley, P., Eds.; Cambridge University Press: Cambridge, UK, 2013.

46. Solomon, S.; Qin, D.; Manning, M.; Chen, Z.; Marquis, M.; Averyt, K.; Tignor, M.; Miller, H.L. Contribution of Working Group I to the Fourth Assessment Report of the Intergovernmental Panel on Climate Change; Manning, M., Chen, Z., Marquis, M., Averyt, K., Tignor, M., Miller, H.L., Eds.; Cambridge University Press: Cambridge, UK, 2007.

47. Beaumont, L.J.; Pitman, A.J.; Poulsen, M.; Hughes, L. Where will species go? Incorporating new advances in climate modelling into projections of species distributions. Global Chang. Biol. 2007, $13,1368-1385$.

48. World Data Center for Climate. Lowe IPCC DDC AR4 UKMO-HadGEM SRESA1B run1. CERA-DB "UKMO_HadGEM_SRESA1B_1" 2005. Available online: http://cera-www.dkrz.de/WDCC/ui/ (accessed on 5 December 2008).

49. World Data Center for Climate. Lowe IPCC DDC AR4 UKMO-HadGEM SRESA2 run1. CERA-DB "UKMO_HadGEM_SRESA2_1" 2005. Available online: http://cera-www.dkrz.de/WDCC/ui/ (accessed on 5 December 2008).

50. World Data Center for Climate. Roeckner IPCC DDC AR4 ECHAM5/MPI-OM SRESA1B run1. CERA-DB “EH5_MPI_OM_SRESA1B_1" 2005. Available online: http://cera-www.dkrz.de/ WDCC/ui/ (accessed on 5 December 2008).

51. World Data Center for Climate. Roeckner IPCC DDC AR4 ECHAM5/MPI-OM SRESA2 run1. CERA-DB “EH5_MPI_OM_SRESA2_1”2005. Available online: http://cera-www.dkrz.de/WDCC/ui/ (accessed on 5 December 2008).

52. World Data Center for Climate. GFDL IPCC DDC AR4 GFDL-CM2.1 SRESA1B run1. CERA-DB “GFDL_CM2.1_SRESA1B_1" 2005. Available online: http://cera-www.dkrz.de/WDCC/ui/ (accessed on 5 December 2008).

53. World Data Center for Climate. GFDL IPCC DDC AR4 GFDL-CM2.1 SRESA2 run1. CERA-DB “GFDL_CM2.1_SRESA2_1” 2005. Available online: http://cera-www.dkrz.de/WDCC/ui/ (accessed on 5 December 2008).

54. Huntley, B.; Green, R.E.; Collingham, Y.C.; Willis, S.G. Climate Atlas of Breeding Birds in Europe; Lynx Edicions: Barcelona, Spain, 2007.

55. Burnham, K.; Anderson, D. Model Selection and Multimodel Inference: A Practical Information Theoretic Approach; Springer-Verlag: New York, NY, USA, 2002.

56. R Core Team Team. R: A Language and Environment for Statistical Computing; Vienna, Austria, 2014. 
57. Gill, F.; Donsker, D. IOC World Bird List 2014, v 4.2. Available online: http://www.worldbirdnames.org/ (accessed on 1 August 2015).

58. Manel, S.; Ceri Williams, H.; Ormerod, S.J. Evaluating presence-absence models in ecology: The need to account for prevalence. J. Appl. Ecol. 2001, 38, 921-931.

59. Thuiller, W.; Brotons, L.; Araújo, M.B.; Lavorel, S. Effects of restricting environmental range of data to project current and future species distributions. Ecography 2004, 27, 165-172.

60. Wisz, M.S.; Hijmans, R.J.; Li, J.; Peterson, A.T.; Graham, C.H.; Guisan, A.; Elith, J.; Dudík, M.; Ferrier, S.; Huettmann, F.; et al. Effects of sample size on the performance of species distribution models. Divers. Distrib. 2008, 14, 763-773.

61. Thomas, C.D.; Lennon, J.J. Birds extend their ranges northwards. Nature 1999, doi:10.1038/20335.

62. Parmesan, C.; Yohe, G. A globally coherent fingerprint of climate change impacts across natural systems. Nature 2003, 421, 37-42.

63. Hickling, R.; Roy, D.B.; Hill, J.K.; Thomas, C.D. A northward shift of range margins in British Odonata. Global Chang. Biol. 2005, 11, 502-506.

64. Dunnet, G.M.; Ollason, J.C. The estimation of survival rate in the fulmar Fulmarus glacialis. J. Anim. Ecol. 1978, 47, 507-520.

65. Coulson, J.C. The population dynamics of culling Herring Gulls Larus argentatus and Lesser Black-backed Gulls Larus fuscus. In Bird Population Studies: Relevance to Conservation and Management; Perrins, C., Lebreton, J., Hirons, G., Eds.; Oxford University Press: Oxford, UK, 1991.

66. Reynolds, T.J.; King, R.; Harwood, J.; Frederiksen, M.; Harris, M.P.; Wanless, S. Integrated data analysis in the presence of emigration and mark loss. J. Agric. Biol. Environ. Stat. 2009, 14, 411-431.

67. Lavers, J.L.; Jones, I.L.; Diamond, A.W. Natal and Breeding Dispersal of Razorbills (Alca torda) in Eastern North America. Waterbirds 2007, 30, 588-594.

68. Frederiksen, M.; Petersen, A. The Importance of Natal Dispersal in a Colonial Seabird, the Black Guillemot Cepphus grylle. Ibis 2000, 142, 48-57.

69. Becker, P.H.; Ezard, T.H.G.; Ludwigs, J.D.; Sauer-Gürth, H.; Wink, M. Population sex ratio shift from fledging to recruitment: Consequences for demography in a philopatric seabird. Oikos 2008, $117,60-68$.

70. Coulson, J.C.; Coulson, B.A. Measuring immigration and philopatry in seabirds; Recruitment to Black-legged Kittiwake colonies. Ibis 2008, 150, 288-299.

71. Kim, S.Y.; Torres, R.; Rodríguez, C.; Drummond, H. Effects of breeding success, mate fidelity and senescence on breeding dispersal of male and female blue-footed boobies. J. Anim. Ecol. 2007, 76, 471-479.

72. Devlin, C.M.; Diamond, A.W.; Kress, S.W.; Hall, C.S.; Welch, L. Breeding dispersal and survival of arctic terns (Sterna paradisaea) nesting in the Gulf of Maine. Auk 2008, 125, 850-858.

73. Coulson, J.C.; Nève de Mévergnies, G. Where do young kittiwakes Rissa tridactyla breed? Philopatry or dispersal? Ardea 1992, 80, 187-197.

74. Phillips, B.L.; Brown, G.P.; Travis, J.M.J.; Shine, R. Reid's paradox revisited: The evolution of dispersal kernels during range expansion. Am. Nat. 2008, 172, S34-S48.

75. Thompson, P. Identifying drivers of change; did fisheries play a role in the spread of North Atlantic fulmars? In Conservation Biology Series; Boyd, I., Wanless, S., Camphuysen, C.J., Eds.; Cambridge University Press: Cambridge, UK, 2006; pp. 143-156. 
76. Fisher, J. The Fulmar Population. Nature 1952, 170, 725-725.

77. Wynne-Edwards, V. Animal Dispersion in Relation to Social Behaviour. Can. Med. Assoc. J. 1963, $88,1255-1256$.

78. Salomonsen, F. The geographical variation of the fulmar Fulmarus glacialis and the zones of marine environment in the North Atlantic. Auk 1965, 82, 327-355.

79. Blois, J.L.; Zarnetske, P.L.; Fitzpatrick, M.C.; Finnegan, S. Climate change and the past, present, and future of biotic interactions. Science 2013, 341, 499-504.

80. Molinos, J.G.; Halpern, B.S.; Schoeman, D.S.; Brown, C.J.; Kiessling, W.; Moore, P.J.; Pandolfi, J.M.; Poloczanska, E.S.; Richardson, A.J.; Burrows, M.T. Climate velocity and the future global redistribution of marine biodiversity. Nat. Clim. Chang. 2015, 4-11.

81. Petitgas, P.; Alheit, J.; Peck, M.; Raab, K.; Irigoien, X.; Huret, M.; van der Kooij, J.; Pohlmann, T.; Wagner, C.; Zarraonaindia, I.; et al. Anchovy population expansion in the North Sea. Mar. Ecol. Prog. Ser. 2012, 444, 1-13.

82. Heath, M.R.; Neat, F.C.; Pinnegar, J.K.; Reid, D.G.; Sims, D.W.; Wright, P.J. Review of climate change impacts on marine fish and shellfish around the UK and Ireland. Aquat. Conserv. Mar. Freshw. Ecosyst. 2012, 22, 337-367.

(C) 2015 by the authors; licensee MDPI, Basel, Switzerland. This article is an open access article distributed under the terms and conditions of the Creative Commons Attribution license (http://creativecommons.org/licenses/by/4.0/). 